\section{あとがき}

1 年の $1 / 7$ 占める西高東低の気圧配置について， 日本全域の降水量分布につき，特異な地域を選んで，
その模様を明らかにしたが，他の6/7の日々について は稿をあらためて論ずることにする。

この報告にあたり, 多田文男・矢沢大二両先生に日頃の御指導を 梁く咸謝いたしたい.（1961年 3 月25日受理）

\title{
UEBER DIE BEREICHE DES WINTERLICHEN NIEDERSCHLAGS IN JAPAN
}

\section{Hideo SUZUKI}

Verfasser hat 365 tägliche Niederschlagskarten von ganz Japan entworfen. Es wird der Zusammenhang zwischen winterlichen Druckverteilungen und den entsprechenden Niederschlagsverteilungen erläutert. 1) Einige inselartige Niederschlagsgebiete sind in Vorderjapan deutlich zu erkennen. 2) Die Regenschatten der Inseln Rishiri, Sado und der Koreanischen Halbinsel sind sichtbar. 3) Die Niederschlagsmenge ist von der Breite des Japanischen Meeres abhängig. An der Nordspitze von Hokkaido und an der Westspitze von Honschu ist das Meer nicht breit genug um Wasserdampf für den Niederschlag zu liefern. Infolge der Vereisung und der Verminderung der Meeresfläche durch eustatische Niveauveränderung im Eiszeitalter muss das Niederschlagsgebiet kleiner gewesen sein. Die Tatsache, dass es in Nord-Hokkaido weit verbreitet eiszitliche Solifluktion gab, beweist, dass das Land schneefrei, also der Niederschlagsbereich wirklich kleiner war.

\section{日本四輪自動車工業の地域的展開*}

\section{北村嘉 行}

\begin{abstract}
摘要 箨者は, 自動車工業の分布を調査することによつて，その地域的展開の一般構造を理解したいと思つた. 自動車工業のような組立工業は，他の機械器具工業などとともに，大都市に分布している11.

自動車工業の地域的展開は, その地域的な立地因子2) の顕現というよりも, むしろ, 親工場となる組立工場を 中心にした地理的な配置構造3) の中で決定される. 自動車工業立地の基体となつたものは, 一般に, 機械工業で ある. 組立工場は, 関連産業と用地とを立地の要件として, 大都市の郊外や埋立地などに立地した. 組立工場の 周辺には単一部品工場と車体工場が分布し, さらに, その外辺へと完成部品工場が分布することによつて, 自動 車工業の核心地域を形成する. やがて, 需要の増大と国防的要因とによつて車体工業に特色のある衛星工業地域 が核心地域から派生した. さらに，その外側には完成部品工業の単独地域が形成されている。このようにして, 自動車工業の統一地域 4 ）工業圈が構成される. 核心地域と工業圈の内部における本工業生産の地理的配置構造 は全く同一であり，生産の增大によつて，核心地域が工業圈に拡大されたと言える。 そして，本工業のこの地域 的展開の構造は，常に一定している.

わが国に扝ける四輪自動車工業の地域構成は，10区分され，3工業圈 2 地方区 1 連節地帯に概括される. 京浜・ 中京・阪神索核心とする三つの工業圈があるが, 中京の部品工業の発達はいまだ不完全であり, 阪神々は部品工 場が分布していない. しかし, 軽自動車の出現や三輪車工業から四輪車生産への進出などによつて, 本工業はさ らに発達し,この地域的展開が充足されよう.
\end{abstract}

\section{緒 言}

1957 年における，全自動車生産数は 707, 261 台，
その生産額は 2,059 億円に達する ${ }^{53}$. 自動車工業は, 全製造業生産高の30\%をこえる機械工業の中でも，

* 本稿は，1961年 1 月，日本地理学会例会に打いて発表したものに加筆したものである.

1）板倉勝高 (1961)：全国大工場の分布. 地理評., 34, p.109. (12月例会要旨).

2）川西正鑑（1939）：工業立地の研究.

3）奥田義雄（1956）：工業位置の分析. 現代地理講座，7，生産の地理，150～167.

4) 木内信蔵 (1951)：人文地理学.

5）自動車工業会・日本小型自動軦工業会（1958）：自動車統計年表. 
$23 \%$ 占めて首位に立つ ${ }^{6)}$. 全自動車生産のうち， 四輪自動車は 181,893 台で戦前の最高時である 1941 年の 4 倍をこえる。また，633，690台保有する四輪 車のうち $83 \%$ は国産車である7 . 日本の自動車工業 は，戦後急激に成長して，わが国の産業の中でも主 導的な地位を占めるようになつた。自動車は，1,500 種 5,000 点 $^{8)}$ と言われる各種の菜材や部品から組立 てられる。したがつて，自動車工業は多くの産業と 関連し，専門の下請部品工業を従え，これらの複雑 な企業系列の組織の上に立つ総合組立工業9)である。 本論は，このような複雑な構造をしている自動車 工業の分布を明らかにすることによつて，その地域 的展開の構造をきわめんとするものである. 分布の 位置やひろがり，地域的展開の大略，各地域におけ る工業発展の歴史などを知ることによつて，自動車 工業に打ける地域形成の過程をつかむ事が出来る. さらに，その素材や部品の流動状況を調べることに よつて，地域と地域が，あるいは地域の内部の様相 が，どのように相扶補完されて一つの生産地域構造 に統一されているかを理解することができるであろ う。しかし，本論では日本全体の概観と，特に，京 浜地域の展閉構造に重きをおいた。

また，問題がいたずらに複雑化することを避ける ため，本論の対象を普通および小型四輪自動車10)の みに限定した、四輪車は自動車の一般的概念とも合 致し，全自動車生産の $26 \% ，$ 保有台数の31\%を占め ているが全出荷額の $55 \%$ に達し，本工業の中核をな す存在である，もちろん，自動車工業の研究として

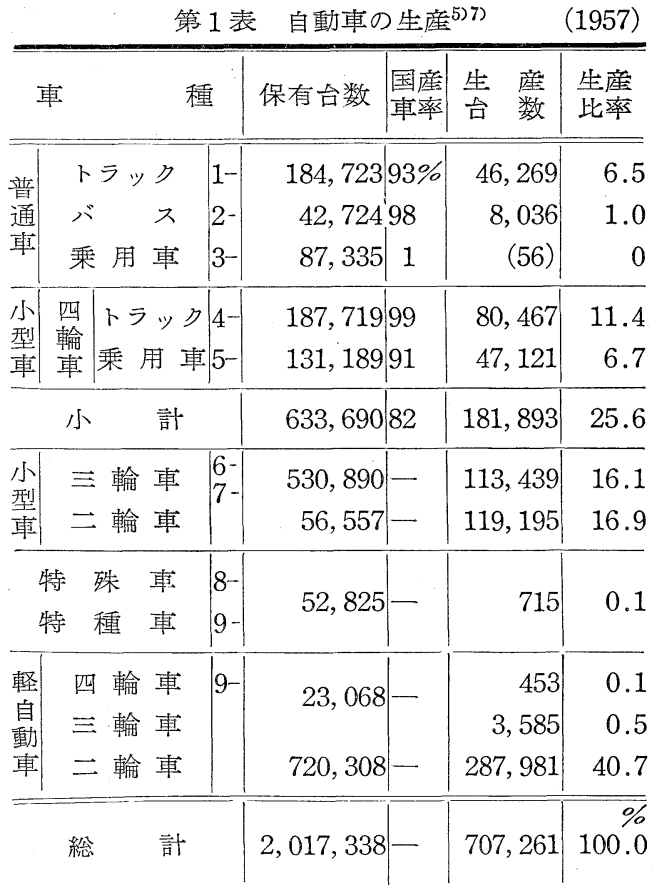

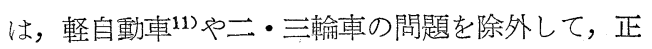
しい需要構造やその産業連関構造 ${ }^{12}$ を理解すること はむずかしい.これらの問題やその他の地域の微細 な分析と，これらの複合された立地構造については， 別に論ずるつもりである.

\section{I 工場の分布}

一般に，“自動車工場” Car Maker と呼ばれるも のは，素材や部品を収集・加工して， line productionによる最後の総組立を行なうものであるが，完 成車に至る一貫生産を行なうのは乗用車部門13)だけ である。バスやトラックは別の Body Makerによ

\footnotetext{
6）通商産業省 (1960)：工業統計表.

7）、日本自動車会議所。日刊自動車新聞社（1959）：自動車年鑑.

8）奥村正二（1959）：自動車. 岩波新書.

9）前揭 7).

10）道路交通取締法第 2 条および同法施行規則第 3 条別表。

11）従来，岡村製作所や鈴木自動車などによつて製造されていたが，今日のように発達したのは，富士重工 のスバル360が1958年に発表されてからのことである.

12）篠原三代平 (1959) : 産業構造.

13）高度なモデルのスタイリングが要求され，一定型式の量産が可能であり，そのモデルがコストや他の部 分の設計に大きく影響される.
} 
つて，自動車に用途を与える車体が架装される。

Car Maker は主してェンジンや車輪を具備して走 行機能をつかさどる車台を組立てるにとどまり，一 般に Chassis Maker と呼ばれる.これらの自動車 の生産に必要な部品の約70\%は，専門の Parts Maker によつて下請け，外製される.すなわち，自動 車工業は，企業構成上，これを三つに区分すること ができる、第一は Chassis Maker であり，その工

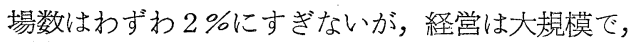
生産附加価值額は全体の $60 \%$ 強を独占する。第二は 約90\%の工場数をかぞえる Parts Maker であり， その工場数は多いが，平均従業員数はわずかに34人，
きわめて小規模な従属的工業である. 第三は Body Maker で，第一ないし第二の中間的性格を有する とは言え，約10\%の附加価值を生産する企業である。

1) Chassis Maker 現在，9社11組立工場あ る。そのほか，若干のトラックを生産する小松製作 所 (小松)，乗用車の岡村製作所 (追浜)，三輪車工 業から小型四輪トラックに進出してきた ${ }^{14)}$ 東洋工業 (広島)，ダイハツ（池田）などがあるが，これら は本論から除外した。 6 社のうち，富士精密・三菱 日本・新三菱の 3 社は他の機械生産と兼業している が，残る 6 社は専業 Maker である。また，組立工 場のほかに，専門の部品工場を自企業内に附属させ

\begin{tabular}{|c|c|c|c|c|c|c|c|c|c|c|c|c|c|}
\hline & 創業 & $\begin{array}{c}\text { 敷地 } \\
\text { 百評 }\end{array}$ & 従業員 & $\begin{array}{l}\text { 附属部 } \\
\text { 品工場 }\end{array}$ & \begin{tabular}{|c|} 
バ \\
$\begin{array}{c}\text { ガソ } \\
\text { 1ン }\end{array}$
\end{tabular} & 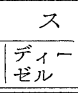 & 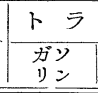 & $\left|\begin{array}{ll}\text { y } & ク \\
\text { ディー } \\
\text { ぜル }\end{array}\right|$ & $\begin{array}{l}\text { 小型ト } \\
\text { ラック }\end{array}$ & 乗用車 & $\mid \begin{array}{l}\text { 売上金 } \\
\text { 百万传 }\end{array}$ & \begin{tabular}{|l} 
資本金 \\
怢万向
\end{tabular} & その他 \\
\hline 民 生・川口 & 1935 & 536 & 1,063 & & & 491 & & 729 & & & 2,680 & 400 & \\
\hline 野 & 1941 & 1,230 & 2,646 & & & 2,018 & & 2,392 & & 3,573 & 11,205 & 2,250 & \\
\hline 富士精密・三鷹 & 1946 & 199 & 1,138 & 荻 篞 & & . & & & 8,582 & 2,007 & 5,862 & 1,335 & 航筀機，ミシン \\
\hline 日本自工・蒲田 & 1935 & 51 & 211 & 品川·大森 & & & & & 1,141 & & 11 & 500 & (三倫車) \\
\hline 三菱目本・ 丸子 & 1933 & 490 & 1,291 & 大井・川崎 & & 1,559 & & 1,177 & & & 1,731 & 3,000 & 造船·造機 \\
\hline 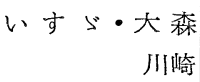 & $\begin{array}{l}1916 \\
1937\end{array}$ & $\begin{array}{r}59 \\
546\end{array}$ & $\begin{array}{r}272 \\
2,302\end{array}$ & 鹤見・来吉 & & 3,078 & 746 & 9,470 & & 2,794 & 21,320 & 3,000 & \\
\hline $\begin{array}{r}\text { 日 産 - 鶴 見 } \\
\text { 吉 原 }\end{array}$ & $\begin{array}{l}1933 \\
1943\end{array}$ & $\begin{array}{r}1,174 \\
883\end{array}$ & $\begin{array}{l}4,924 \\
1,573\end{array}$ & 戸 塚 & 278 & 230 & 10,117 & $2,592^{2}$ & 26,937 & 18,786 & 30,892 & 4,200 & \\
\hline ト $\quad \exists \quad$ タ & 1936 & 642 & 5,529 & & 175 & 197 & 14,104 & 1,743 & 43,423 & 19,885 & 44,117 & 6,686 & \\
\hline 新三菱 - 名古屋 & 1950 & 2,256 & - & 京 都 & & & & 3,307 & & & 12,011 & 11,200 & 造船・造機 \\
\hline $\begin{array}{ccc}\text { そ } & \text { の } & \text { 合 } \\
& \text { 計 }\end{array}$ & & & & & 463 & 570 & $\begin{array}{r}20 \\
28\end{array}$ & $\begin{array}{r}55 \\
18,0588\end{array}$ & $\begin{array}{r}339 \\
80,422\end{array}$ & $\begin{array}{r}76 \\
47,121\end{array}$ & & & \\
\hline
\end{tabular}

ているものが 6 社 9 工場ある.

9 社 11 組立工場のうち，日産・いすら゙・三菱日本 -日本自工 ${ }^{15)}$ ・富士精密・日野・民生の 7 社 8 工場 は京浜地域に集中し，新三菱やトヨタは中京地域に， 日産吉原だけが駿河湾頭に位置している。すなわち， 日産吉原工場を除けば，組立工場はいずれも京浜・ 中京のごとき，大市場地域であり大工業地域である
ところに立地している，これらのうち，新三菱や日 産・いすら゙・日本自工などの 5 工場はいずれも臨海 埋立地区に，残る 6 工場は郊外地区に立地し，いず れも大都市の辺縁部に隣接している，なお，同様の 性格を有する地域と思われる阪神には Chassis Maker が現存していない.

2）Body Maker 通産省および日本自動車車

14）本格的生産は，いずれも1958年から.

15）三輸車 “くろが衩” Maker であつた日本内燃機と，旧来の小型四輪車 “オオタ” maker であつたオオタ 自動車が合併したもので，現在の東急くろがねに引継がれている. 


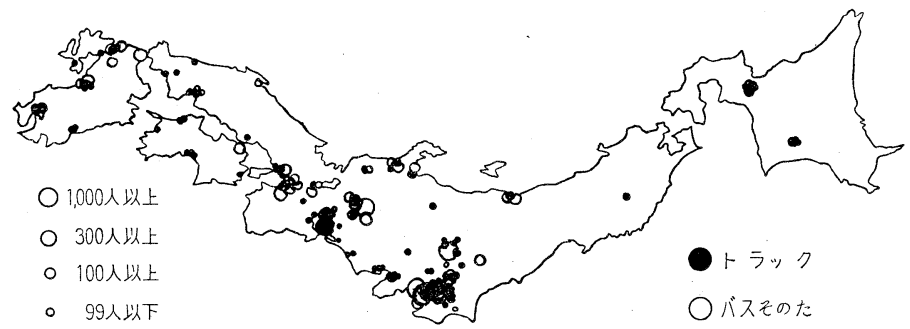

第 1 図車体工場の分布

北陸や北九州もまた同一の性格を 有する。

Body Maker の分布は, Chassis Maker の集中的・局地的である のに対して，分散的・平滑的であ る。すなわち，Chassis Maker は京浜と中京の両地域に集中する が，Body Maker は全国に広く分 布し，各地方市場の需要に対応し 体工業会の名簿によつて，88社135工場 ${ }^{6)}$ が調查さ ている。一般に，京浜・中京阪神の核心地域の大き れた。最も集中的に分布しているのは関東地方の 55 さは，それぞれの地域が後背としている市場の容量 \%で，特に京浜工業地域は $40 \%$ の高率を占めている。 に比例し，全国の地方都市に散在している中小工場 は各地方各地の局地的需要に照応して，主としてト ラックを生産するむのである.これに対して，衛星 工業地域等の車体工業地域は，量産可能な規格化さ れた車体やバスや特装車などの特殊技術を要するも のを生産して，全国的市場を大きく分割，供給して いる.

関東地方の工場分布のうち，北関東の桐生・伊勢

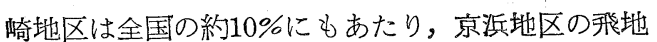
を形成する.このように，多数の工場が集中的に分 布している核心地域の周辺に，少数の工場集団が半 独立的に集中して，衛星工業地域を構成することは 他の 2 地方についても観察される.すなわち，中京 の名古屋・犻谷核心地域に対する岐皁・犬山地区， および阪神の臨海核心地域に対する京都・宇治地区 がそれである。これらの衛星工業地域は，いずれも 大規模なバス Maker を中心にして形成されて扣り，

3) Parts Maker 部品工業は Chassis Maker の系列下に强い支配を受け，その実態を把握するこ とは困難である．ここでは，通産省および自動車部 品工業会の資料によつて，その企業数約 $280 ， 307 工$ 場が明らかにされた18).しかし，筆者が 2 Chassis Maker の下請工場を全数調査した結果から推定す ると，少なくともその $3 \sim 4$ 倍の工場が存在するも のと思われる，それらの中には，自動車の部品工業 であるか，他の機械工業や金属工業に属すべきか，

16）同じ1957年についても，車体工業会会員は105工場，通産省：機械器具工場名簿および日刊工業新聞社： 工場通覽を総合すると 132 工場，通産省：工業統計表によると 215 工場かぞえられるが，筆者は 88 社 135 工場を Body Maker と認定した。

17）購買者や補修依頼の需要に応じて，年間数台の車体を手工業的に架装するものがある。

18）二・三輪用生産 Maker を含めて，1957年の部品工業会調查会員数は $227 ＼mathrm{~ 会 員 外 を 含 め て ， 324 社 ， 機 ~}$ 峨器具工場名簿抢よび工場通覽から総合されるもの 842 工場，工業統計表によれば 3, 705 工場がかぞえら れる。そのうち，四輪車用 Maker は，日本発条，佐藤竜三氏によれば延べ 1,274 社実442社と調查されて いる，(佐藤竜三 (1959)：自動車産業はどのように経営されているか。ダイヤモトド産業全書， 1 ，自動 車，p.296参照）筆者は，そのうちの延べ565工場中 307 工場の実態を調査することができた。しかし，I 社の組立用下請部品 Maker の総数は約 400 工場にのぼり，そのほかにサービス部品のみを納入するもの 32 社をかぞえられる。 


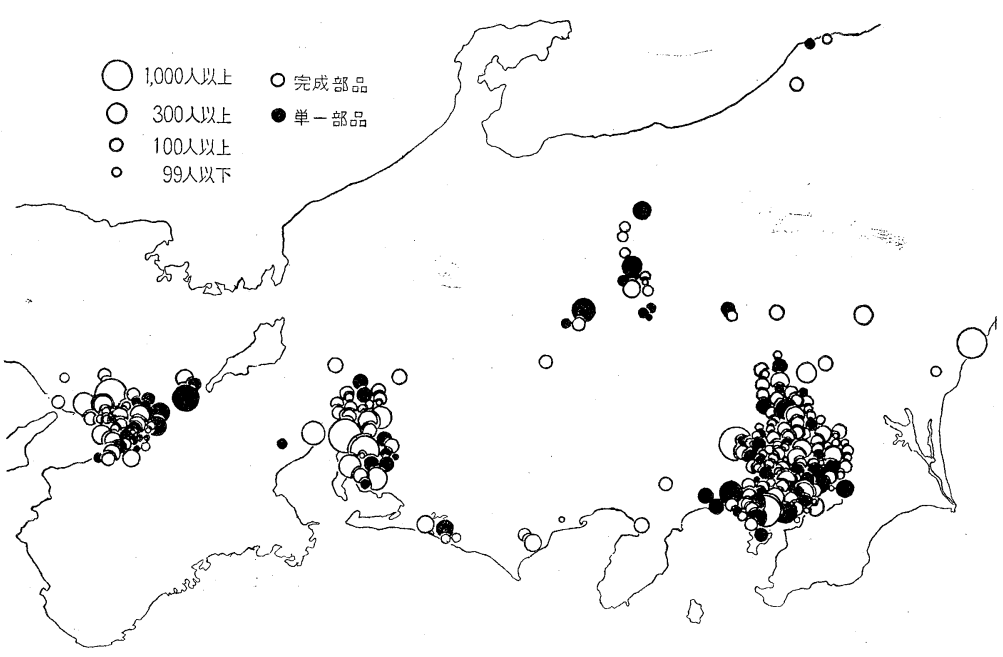

第 2 図部 品工場 の分布

所属の不明瞭なものが多い。また，Parts Makerの 作業と生産の内容はきわめて多様で，関連産業，ひ いては全工業と深いつながりを持つ。

Parts Maker の分布は，関東以西・近畿以東の中 央日本部に限られている，京浜・中京・阪神の三大 地域のほか，北信地区にも集中し，東海や新潟など の北関東周辺部にも若干分布している，最も高い集 中を示すのは，与野から横浜に至る京浜核心地域の 約140工場で，3 都県を合わせると184工場が分布し ている、これを業種別にみると，鋳造・鍤造・プレ

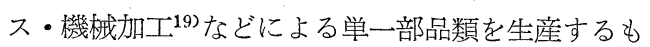
のは核心地域の中心地区に分布し，Chassis Maker の周因に集中する，他方，電装・用品・ばね・工具 などの完成部品類 ${ }^{20)}$ を生産するものは，企業規模も 比較的大きく，その分布は一般に分散的である.

阪神地域は Chassis Maker が分布しないわりに Parts maker は多いが，その74\%までが補修用部品 の生産を専業とするものである. 特に，外車用補修
部品の生産はこの地域が独 占的であり，その輸出業者 は25社中 14 社もこの地域に 集中している。 また長野の 17 Parts Maker 中, 7 企 業は補修用生産のみに従事 し，3企業はばね・ピスト ンなどを生産する独立的な ものであり，残る 1 企業は 中京地域の，5 企業は京浜 地域の Chassis Makre に 系列化されている。すなわ ち, 北信地域の Parts Maker は，補修用の単一部品 を生産するものと京浜地域の組立用完成部品類を生 産するものとに大分され，これらは新潟・荻城・群 馬などにある Parts Maker とともに，大京浜の外 郭地域を形成する。 また，東海地域に分布する一連 の自動車工場群は，両三業態にわたつて Chassis Maker の分布する京浜・中京両地域の結節的意義 を有する.

4）地域区分このような業態の分布の重合のし かたによつて，自動車工業の地域構成は10区分され さらに京浜・中京・阪神を中心とする 3 工業圈と 1 連節地帯 2 地方区に大分される.

A 関東自動車工業圏

1. 京浜自動車工業地域

(Chassis, Body \& Parts-Makers)

\section{2. 北関東車体工業地域}

(Body \& Parts-Makers)

3, 北信部品工業地域 (Parts-Makers)

B 中部自動車工業圈

19）これらの部品の分類は，自動車部品工業会のそれにならつた。

20）機関用のラジェーター・ポンプ・クリーナー類を含む.また，ばねは単一部品と言うべきものも多いが 企業的に大規模・独立的な場合が多いので，この類に含ませた． 
4. 中京自動車工業地域

(Chassis, Body \& Parts-Makers)

5. 美濃車体工業地域

(Body \& Parts-Makers)

C 関西自動車工業圈

6. 阪神部品工業地域

(Body \& Parts-Makers)

7. 京宇車体工業地域

(Body \& Parts-Makers)

D 東海連節工業地带

8. 東海節工業地域

(Chassis, Body \& Parts-Makers)

E 北陸自動車工業区

9. 北陸車体工業地域 (Body-Makers)

F 九州自動車工業区

10, 北九州車体工業地域 (Body-Makers)

\section{II 地域の形成}

自動車は，1897年，横浜に渡来した21)。1901年に は銀座で委託販売をするものが現われ，1903年には
日本に打いて始めて組立てられ，広島でバスに使用 せられた，最初の純国産車は，1904年，岡山で山羽 式二汽筒車が試作されている22)，欧州の軍事事情に 刺激されて研究を重ねた陸軍は，1910年，大阪砲兵 工廠で軍用貨物車第 1 号を試作した。以来，日本の 自動車工業は軍の保護を受けて育成されることにな り，トラックの生産に重きが扔かれてきた。 わが国 の自動車工業は，1918年の軍用自動車補助法によつ て創生し，1936年の自動車製造事業法によつて確立 された.これらの軍事的保護策が語られるたびごと に，阪神地域でも，機械工業から自動車生産への進 出が多数試みられたが，不幸にして永続したものは ない.わずかに存続し得た京浜地域の諸工場でも， 1941年の第 2 次大戦開始と同時に衰退し始め，他の 軍需生産に転換して行つた。ししい，戦後はふたた び起る存続可否論の中でいち早く復活し，着実な発 展を再開した。乘用車工業の確立は, 朝鮮特需の後 に行なわれた一連の技術提携の結果である。また， 最近は小型四輪トラックや軽自動車の需要が増大し，

第 3 表工業 生産 の推移・

\begin{tabular}{|c|c|c|c|c|c|c|c|c|}
\hline 歴 年 & 保有台数 & 生産台数 & 四 輸車 & トラック & バ & x & 小型トラック & 乗 用 車 \\
\hline 1900 & 2 & & & & & & & \\
\hline 1905 & 18 & & & & & & & \\
\hline 1910 & 205 & & & & & & & \\
\hline 1915 & 1,244 & & & & & & & \\
\hline 1920 & 9,999 & & & & & & & \\
\hline 1925 & 29,164 & & & & & & & \\
\hline 1930 & 89,222 & & & 458 & & & & \\
\hline 1935 & 176,252 & 15,447 & 5,089 & 1,181 & & $\leftarrow$ & 3,908 & $\leftarrow$ \\
\hline 1940 & 217,219 & 54,293 & 46,041 & 43,706 & & $\leftarrow$ & 2,335 & $\leftarrow$ \\
\hline 1945 & 144,351 & 6,464 & - & 6,084 & & -1 & - & - \\
\hline 1950 & 387,543 & 74,686 & 31,597 & 17,576 & & 3,052 & 8,926 & 1,593 \\
\hline 1955 & $1,463,749$ & 400,820 & 68,932 & 22,352 & & 4,807 & 21,505 & 20,268 \\
\hline 1960 & $3,341,017$ & - & 403,919 & 125,231 & & 8,437 & 141,267 & 128,984 \\
\hline
\end{tabular}

21）尾崎正久（1942）：自動車日本史。この項の史実は，同書によるところが多いことを記して，著者の労苦 に感謝する。

22）䉓機修理業山羽商会は，依頼を受けて，神戸外人商館の見本を参考に蒸気車を完成したが，乗用車用バ ルーンタイヤを使用して失敗し，これ 1 台で製造を断念した。 
[34. 6

第 3 表 (付表) 大正年閒国産台数

\begin{tabular}{|c|c|c|}
\hline 石川島造船 & 小型乘用, $1 \mathrm{t} \cdot 1 \mathrm{t}$ 半貨物 & 259 \\
\hline 東京ガス電 & $1 \mathrm{t} \cdot 1 \mathrm{t}$ 半貨物車 & 103 \\
\hline 快＼cjkstart進 & $4 / 3 \mathrm{t}$ 貨 & 13 \\
\hline 実用自動車 & 小型 乗 用 車 & 76 \\
\hline 白 楊 & 小型 乗 用 車 & 95 \\
\hline オリエント & 中 型乗 用 車 & 13 \\
\hline
\end{tabular}

月産 1 万台工場 ${ }^{23)}$ が出現するなど，わが国の自動車 工業は新たな発展期を迎えている。

1）発生期（1897～1915年）銀座で始めて組立 てられた自動車は，アメリカ自動車界を視察に行つ て中途で変心し，持帰られたガソリンエンジンをも とに製作された ${ }^{24)}$. 主任は当時の先進的機械技術を 体得しているウラジオ帰りの電気技師であり，車体

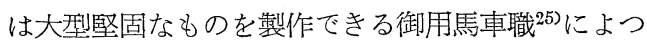
た。やがて，麻布周辺の車鍛冶屋を中心に，自動車 を試作する数工場が出現した。この車体工業的な自 動車工業の発生形態は, アメリカ Michigan 湖周辺 における場合と類似している26). しかしわが国では， これらの諸工場が発展せず，最も永続したタクリ一 でも1907年から1909年までの17台に終つている27). わが国の自動車工業は，車鍛冶屋ではなく，次の快 進社以降のように，機械工業を立地の基体とするも のによつて創生された。
自動車工業が都心の南部に分布する車鍛冶屋と結 びついて発生したことは，東部に分布する本所の一 般鍛冶職と結びついて発展した自転車工業と著しく 対照的である ${ }^{28)}$. 以後, 自転車工業は江東地域に, 自動車工業は京浜臨海地域を中心に発展することに なつた. スイフトの輸入組立を行なつていた快進社 が，DA T 1 号を完成したのは1911年である.

2）創生期（1916～1935年）東京工廠に自動車 部品を納入していたガス電は，補助法の公布を見越 して，広大安価な土地の得られた大森の埋立地で， 1916年から本格的生産を開始した ${ }^{29)}$. 法 ${ }^{30)}$ が公布さ れると，そのほかにも東京 2 社・大阪 3 社・京都 2 社・神戸 1 社が，造船工業またはその他の機械工業 から本工業生産へ進出してきた. しかし，存続した のは 3 社だけである. 石川島造船は，ウーズレーと 技術提携して1920年に深川の専門工場を建設し， 1927年に分離独立された。快進社は，1918年に土地 を求めて郊外の落合長崎に移転したが，震垈にあつ て大阪に再転，その販売会社であるダット商会に吸 収された

関東大震災は，わが国の自動車需要を急激に普及 させて外車の輸入を増大し, 外資進出の好機を与え た. 1924年には Ford が横浜に組立工場を設立し， 続いて1926年には G. M. が大阪に誘致された。需

23） 1960年に，トヨタの全車種を合わせたもの，アメリカでは， 1 工場 1 車種月産 1 万台が自動車工場の経 営限界とされている。

24）尾崎正久（1952）：日本自動車車体工業史。4.

25）馬車屋は，一般に，自動車の製作に協力的でなかつた。そこで，宮内省御用をつとめ，1960年の献上車 を修理したことのある間宮に依頼された。

26) M. Denison (1956): The Power to go the Story of the Automotive Industry. 井戸剛 (1959) 訳 : 自 動車物語. $38 \sim 43$.

27）自動車は，チェンドライブからシャフトドライブへ変つたが，日本にはこれを作り得る機械がなかつた。 この東京自動車製造所は，最初の販壳商が前記自転車と合併することにより，最初の組立者となり，さら に改組されたものである.

28）竹内淳彦（1960）：日本における自転車工業の立地. 地理評, $33 ， 412 \sim 424$.

29）いすら゙自動車株式会社（1957）：いす心゙自動車史.

30）日本人または同等法人にして，資本抢よび議決権の過半数を日本人が所有し，年産 100 台以上の一定規格 車を作るものに対して 1 台 3,000 円以内の補助金が与えられた。 そのほか，購買補助金・維持補助金が需 要者に交付された.

31）奥村正二（1960）：自動車工業の発展段階と構造. 現代日本産業講座，V，246～268. 
要の増大は地方の車体工業を興隆させたが，外資の 独占が自動車工業の成長を圧迫することになつた。 そこで，企業の集中による強化や国産品愛用運動， 標準車の設計などが行なわれた。ダットは，1926年 に大阪実用自動車 ${ }^{32}$ と合併し，さらに1931年には， 戸畑鋳物の資本を中心にした関連産業の系列化が行

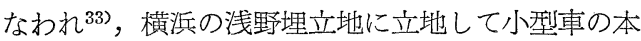
格的生産を企画した，石川島は，標凖車問題の推進 に際して，1933年にダットと合併して自動車工業と 改名している。

しかし，機械器具工業の基礎となる工作機械工業 の発達が遅れているわが国では，強い軍事的行政力 によらない限りその発展を計ることができなかつた。 1932年の関税改正によつて，輸大部品が完成車なみ の35\%に引上げられると，外資組立車の価格は上が り，既に輸入されている外車用の補修部品を生産す るものが東京や大阪に多くなつた ${ }^{34)}$.これらの町工 場は，国産組付用の部品工業に成長する重要な基盤 となつたものである。

\section{3）確立期（1935～1945年） 1935年の自動車工}

業確立要綱を経て，翌年，事業法 ${ }^{35)}$ が公布された。 これは，三井・三菱両財閥の積極的参加を得て軍需 自動車工業の確立を計らんとするものであつたが， 拒まれて，日産とトヨタのために制定されることに なつた。豊田織機は，か秝て本工業への進出を企画
していたが，1935年に挙母の広大な敷地を購入し， 関連生産部門の整備を図つて，1937年，独立した ${ }^{36)}$.

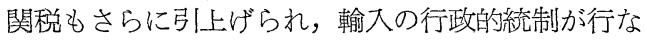
われるに至つて，外資の後退が余儀なくされた。

自動車工業は，1933年の共同販売会社設立を経て， 1937年にガス電と合併し，鶴見工場を建て，標準車 いすら゙の大量生産工場を川崎に新設した．1938年に は，軍需生産の国防的配置が指示されて，日野工場 の建設に着手された ${ }^{37)}$. 1932年から始まつた三菱造 船神戸バス製造所と1933年から始まつた三菱航空東 京エンジン製作所の設備が移転されて，下丸子工場 が新設された. 1912年以来，玩具の製造を行なつて きた日本自工の前身も，蒲田工場を新設した。その ほか，普通・小型，計10社が発生・拡充して本工業 の基礎が確立され ${ }^{38)}$ ，専業大手 3 社は競つて植民 地 ${ }^{399}$ に進出した。

しかし，大半を曘需消費して，再生産されない市 場構造に立脚するわが国の機械工業は40)，不安定・ 非発展的なものであつた. 1941年を頂点として生産 は下降し，資材や需要の相つぐ統制もむなしかつた。 産業優先順位は下落し，バスは1941年，乗用車は 1944年に生産停止され，自動車工業までもが航空機 用部品の生産などに転撸させられて行つた。 日産吉 原は，1943年，そのために新設された。 また，大戦 の激化によつて関連産業の疎開が行なわれ，部品工

32）久保田鉄工の資本と技術を背景に1919年創設された。前揭29）171～174.

33）山本惣治 (1938)：自動車. ダイモンド産業全書，7，p.103. 安来製鋼・東亜電機・不二塗料などを企業 集中した。

34）木村敏男（1959）：日本自動車工業論。社会科学双書， 21，83～84. また，車輪工業の前身も日産の横浜 工場も，最初は，相当量のフォード，シボレー用部品を生産していた。

35）資格生産量が3,000台に引上げられ，Ford は12,360輛，GMは9,470輛に制限された。適用者に対しては， 所得税・営業取益税・工作機械輸入関税が色除された。

36）トヨ夕自動車株式会社（1959）：トヨ夕自動車20年史。挙母工場の完成に先立つて，現在の愛知製鋼や日 本笔装・トヨタ車体の前身が整備拡充された。

37）前揭29), p61.

38）中村静治（1957）：日本の自動車工業. 57〜 58 .

39）1936年，奉天同和（いすぐ）。1939年，満州自動車（日産）。1941年，華中豊田。同年，ジーゼル自工朝 鮮 (いす心゙).

40）豊崎稳（1941）：日本機械工業の基礎構造. p.423. 
業の分布が外辺地域に拡大された.

4）発展期（1946～1957年） 1945年 9 月，まず, トラックの民需生産が許可された。 戦後インフレの 中で，1947年の自動車復興会議をまつまでもなく， 次第に蹯開施設も回収されて，まず，小型車の生産 が急速に回復した。三菱で丈子や日野重工などは， PDあるいは管理工場として再生し，富士自はその ために新発足した。航空機工業から富士精密が，続 いて1949年のバスを最後にした全面的生産制限解除 によつて，富士重・川航・金沢などの衛星工業地域 に分布していた航空機産業が，その特殊技術と生産 設備を活用して，バス車体やヂーゼル車工業に転換 し，車体工業地域を形成した。疎開産業の中には引 上げてもとに医るものがあつたが，定着したものは 地方の労働力や地方の工業化と結んで，外辺部品工 業地域を形成することになつた。朝鮮特需によつて 需要は増大し，小型四輪トラック等の一般民需む増

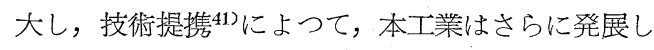
た.

日本の自動車工業の発展と確立は，軍事行政の保 護と外国技術提携の結果である.

\section{III 工業の立地}

1）原料 種類が非常に多い中で，おもなものは 鉄鋼と銅などの非鉄金属，およびタイヤのゴム，ガ

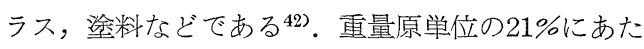
る銑鉄はもとより，43\%を占める普通鋼鋼材でも， 同生産額の $2 \%$ を本工業が消費する状態である。こ れらは，大都市の卸商から Parts Maker の加工を 経て，Chassis Maker に供給されることが多い.自 動車工業とこれらの鉄鋼業の間には，立地上の規制 関係が認められない。これに対して，25\%を必要と
第 4 表 普通型トラック 1 台の原料

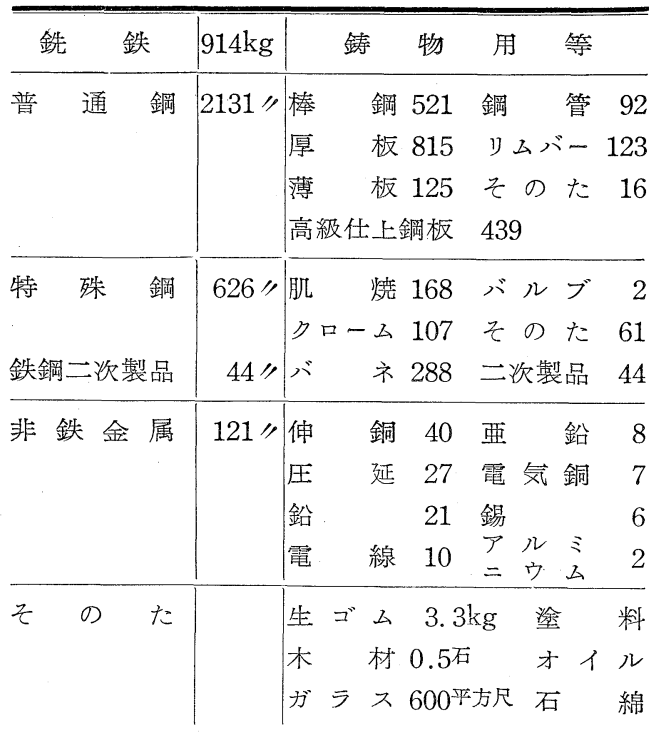

する特殊鋼鋼材は同生産額の $22 \%$ にある。そこで Chassis Maker は資本系列を結んで，地理的に余り 遠くない所に同工業を立地させている，日産の東京 製鐝，トヨタの愛知製鋼，いすら゙の特殊製鋼などで ある.そのほか，四輪車用タイヤチューブは全ゴム 消費量の約 $1 / 3$ にあたり，富士精密は B S の企業憗下 にあるが，タイヤ工業もまた独自の立地形態をとる ものである、そのほか，塗料やガラス工業などとの 間にも，企業系列を結ぼうとする動きが見られるが， 一般には，原料工業と自動車工業との閒の立地関連 はほとんど認められない.

2）部品 Chassis Maker 9 社の原価構成に占め る原材料費は約70\%であるが，その約65\%は Parts Maker の生産によるものである43). Parts Maker の生産の77\%が四輪 Chassis Maker に出荷され44), 75\%が親工場の下請注文による45). Body Makerに

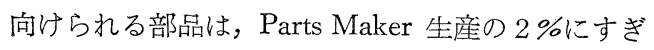

41） 1952 年，日野ニルノー. 1952 年，日産ニオースチン，1953年，いすぶニヒルマン. 1953 年，新三菱=ウ イリス。そのほか，三菱日本二カイザーや，部品工業界でも多くの技術提携をするものが現われた。

42) 寺沢市兵衛 (1958) : 自動車工業と鉄鋼需要. 鉄鋼界 2 月号.

43）前揭18).

44）自動車部品工業会（1959）：自動車部品生産動向調查（昭和32年).

45）中小企業庁（1955）：中小下請工場実態調査. 


\begin{tabular}{|c|c|c|c|c|c|c|c|c|c|c|c|c|c|c|c|c|c|c|c|c|c|}
\hline \multicolumn{9}{|c|}{ 業種別 分類との品種 関 連 } & & & \multicolumn{2}{|c|}{ メーカー } & $\mathrm{T}$ & $\mathrm{N}$ & $\mathrm{I}$ & $\mathrm{H}$ & M & $\mathrm{B}$ & $\mathrm{F}$ & $\mathrm{S}$ & $\mathrm{O}$ \\
\hline \multirow{2}{*}{$\begin{array}{l}\text { 電 } \\
\text { 装 }\end{array}$} & 鋳 & 鍛 & 機 & ば & 部 & 用 & & 工 & & & \multirow{2}{*}{$\begin{array}{l}\text { 分 } \\
\text { 類 } \\
\text { 数 } \\
\end{array}$} & \multirow{2}{*}{$\begin{array}{l}\text { 工場数 } \\
\text { 平 } \\
\text { 均 } \\
\end{array}$} & 72 & 83 & 72 & 70 & 54 & 57 & 67 & 46 & 44 \\
\hline & 造 & 造 & I & 永 & 品 & 品 & ス & 具 & & & & & 70 & 71 & 69 & 63 & 37 & 47 & 49 & 35 & 40 \\
\hline \multirow{8}{*}{12} & 7 & 4 & 6 & 1 & 16 & & & & 機 & 関 & 33 & 56 & 57 & 66 & 72 & 63 & 48 & 45 & 45 & 14 & 45 \\
\hline & & & & & & & & & 電 & 装 & 11 & 65 & 76 & 91 & 91 & 64 & 27 & 45 & 73 & 54 & 64 \\
\hline & 3 & 9 & 5 & 1 & 8 & & & & 伝 & 導 & 25 & 54 & 68 & 60 & 50 & 54 & 62 & 67 & 50 & 42 & 37 \\
\hline & 3 & & 1 & 2 & 8 & & & & 㲘 & 架 & 13 & 65 & 69 & 77 & 62 & 85 & 62 & 62 & 54 & 62 & 54 \\
\hline & & & & & & 22 & & & 用 & 品 & 21 & 70 & 86 & 86 & 51 & 86 & 67 & 76 & 67 & 71 & 67 \\
\hline & 1 & & & & 1 & 1 & 7 & & 車 & 台 & 9 & 44 & 67 & 56 & 89 & 56 & 33 & 33 & 22 & 11 & 33 \\
\hline & & & & & & 5 & 5 & & 車 & 体 & 9 & 36 & 67 & 78 & 33 & 44 & 0 & 0 & 56 & 22 & 22 \\
\hline & & & & & & & & 5 & & 具 & 4 & 42 & 100 & 50 & 100 & 50 & 0 & 50 & 25 & 0 & 0 \\
\hline
\end{tabular}

ない. Chassis Maker と Perts Maker の結合関係 は高い. 外注度の高いものは用品・電装・䊢架伝導 品等の完成部品類で，低いものは車台および車体用 部品や機関用単一部品類である. バッテリー・ば ね・ベアリングなど，前者の工業生産が自動車工業 に依存する度合は高いが，経営規模は比較的大きく， 自動車以外の工業のためにも兼業している場合が多 い.これに対して，後者の鍛鋳造や機械加工を行な ろものは，同生産工業としては自動車工業に依存す る度合は低く，一般に小規模であつて，自動車工羓 向けの生産を行なうものとそうでないものとにはつ
$\%$

\begin{tabular}{|c|c|c|c|c|c|}
\hline \multicolumn{5}{|c|}{ 自動車工業向け出荷率 } & $\%$ \\
\hline タ & $1+$ & • チ & 그 - & ブ & 62.6 \\
\hline ハi & シ & $\bar{\gamma}$ & リ & - & 44.1 \\
\hline ヘ & 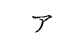 & リ & У & グ & 36.2 \\
\hline ば & & & & ね & 80.8 \\
\hline 歯 & & & & 車 & 20.3 \\
\hline ダ & イ & 力 & ス & ト & 22.2 \\
\hline$k_{2}$ & & & & じ & 11.0 \\
\hline 鍤 & & 造 & & 品 & 22.2 \\
\hline$\checkmark$ & ル & $ヤ$ & ブ & ル & 27.7 \\
\hline 特 & & 殊 & & 鋼 & 30.5 \\
\hline
\end{tabular}

第 7 表 部品工業の従業員規模と専兼 度 ${ }^{46)}$ (1955)

\begin{tabular}{|c|c|c|c|c|c|c|c|c|c|c|c|c|c|c|c|c|c|c|}
\hline \multirow{3}{*}{ 従 業 員 規 模 } & \multirow{3}{*}{$\begin{array}{l}\text { 電 } \\
\text { 装 }\end{array}$} & \multirow{3}{*}{$\begin{array}{l}\text { 鋳 } \\
\text { 造 }\end{array}$} & \multirow{3}{*}{$\begin{array}{l}\text { 鍛 } \\
\text { 造 }\end{array}$} & \multirow{3}{*}{$\begin{array}{l}\text { 機 } \\
\text { 工 }\end{array}$} & \multirow{3}{*}{$\begin{array}{l}\text { ば } \\
\text { ね }\end{array}$} & \multirow{3}{*}{$\begin{array}{l}\text { 部 } \\
\text { 品 }\end{array}$} & \multirow{3}{*}{$\begin{array}{l}\text { 用 } \\
\text { 品 }\end{array}$} & \multirow{3}{*}{$\begin{array}{l}フ^{0} \\
レ \\
ス\end{array}$} & \multirow{3}{*}{$\begin{array}{l}\text { 工 } \\
\text { 具 }\end{array}$} & \multicolumn{3}{|c|}{ 内 } & \multicolumn{3}{|c|}{ 兼 } & \multicolumn{3}{|c|}{ 業 } \\
\hline & & & & & & & & & & 電 & 鋳 & 鍜 & 機 & ば & & 用 & & \\
\hline & & & & & & & & & & 装 & 造 & 造 & I & ね & 品 & 品 & $\begin{array}{l}2 \\
\pi\end{array}$ & 具 \\
\hline ～49人 & 14 & 17 & 4 & 13 & 6 & 28 & 22 & 9 & 5 & & 3 & & 3 & 1 & 4 & 2 & 1 & 2 \\
\hline $50 \sim 99$ & 4 & 2 & 5 & 11 & & 15 & 10 & 2 & 9 & & 1 & 1 & & & 2 & 2 & & 1 \\
\hline $100 \sim 299$ & 3 & 7 & 5 & 16 & 6 & 21 & 18 & 8 & 1 & 3 & & 1 & 4 & 2 & 3 & 5 & 1 & \\
\hline $300 \sim 499$ & 2 & 2 & & 2 & 1 & 9 & 4 & 2 & & & & & 2 & & 3 & 5 & 1 & \\
\hline $500 \sim 999$ & 2 & 2 & 1 & 1 & 1 & 7 & 4 & & & & & 1 & 1 & & 5 & & & \\
\hline $1,000 \sim$ & 3 & 1 & 1 & & & 3 & 1 & & & 2 & & 1 & & & 1 & 1 & & \\
\hline 兼 & 77 & 67 & 61 & 81 & 78 & 80 & 80 & 82 & 87 & 3 & 14 & 8 & 5 & 6 & 7 & 1 & 5 & 14 \\
\hline
\end{tabular}

46） 日本機械工業連合会・自動車部品工業会（1957）：自動車部品工業の実態. 
きり区別される。したがつて，自動車工業の Parts Maker であるこれらの工業の專業度は高くなつて いる. 完成部品 Maker の経営は生産性が高く，技 術的にも高度な專門を有しているが故にその存立意 義があり，一般に，関連産業としてのその工業独自 の立地形態をとる。しかるに，単一部品 Maker は 小規模・被支配的であつて，Chassis Makerの周辺 に集中している.

3）労働 Chassis Maker の Parts Maker 依存 度は，規模が大きくなるにしたがつて高く，近年ま すます高くなつている. Parts Maker は，朝鮮特需 の増大したころ, Chassis Maker の企業不安定性を 転嫁されて増大した。しかし，今日の Parts Maker
は Chassis Maker の低賃労衝を分担するものであ つて，経済二重構造の下部を形成する，素材や部品 の価格が国際的に高いわが国では，企業の合理化と 低貨労働の確保が強いられる. Chassis Maker の平 均賃金が約29,000円で製造業の平均を上回つている が，2\%の女工と $7 \%$ 臨時工を起用し，さらに， 農閑期青年層の労働力も確実な労務計画47)の中に組 込まれょうとしている，Parts Maker の平均賃金は 18,500 円で，機械工業の平均さえも下回つている ${ }^{48)}$ 女工比率は $25 \%$ 上がり，臨時工は $35 \%$ 反んで いる ${ }^{49)}$ 。特に完成部品 Maker よりも，単一部品 Makerにこの傾向が強い，低賃労働が経営存続のた めに利用される価值は高い50)。しかし，それは自動 第 8 表自動 車工業の経 営46)

\begin{tabular}{l|rrrrrrrrr|r|r|r}
\hline & 電装 & 鋳造 & 鉎造 & 機工 & ばね & 部品 & 用品 & プレス & 工具 & 平均 & 車台 & 車体 \\
\hline \hline 附加価值生産性 & 468 & 830 & 387 & 359 & 441 & 426 & 376 & 365 & 436 & 398 & 632 & 323 \\
平 均 賃 金 & 227 & 171 & 178 & 174 & 173 & 192 & 156 & 225 & 155 & 185 & 290 & 一 \\
総資本総利潤率 & 17 & 13 & 17 & 14 & 9 & 17 & 14 & 18 & 25 & 15 & 19 & - \\
労 務 賃 比 & 19 & 27 & 16 & 19 & 13 & 18 & 15 & 17 & 16 & 18 & - & 22 \\
原 材 料 比 & 51 & 38 & 43 & 51 & 62 & 56 & 61 & 47 & 41 & 52 & 63 & 56
\end{tabular}

車工業のみの特殊性でもなく，また，これらの労働 力が当該工業地域内で充足されるものでもない，日 産の農工労務者登録制度は東北地力を主対象とし， トヨタの周辺部品工場でも中小規模 Maker の臨時 工は中・四国，九州加多く求められている. 生産 技術が単純で補修用市販品の多い用品類 ${ }^{61)}$ は，北信 地域で作られるものも多く，地方の低賃労働と結び ついて立地したとも言える。しかし，この場合も， 日本の年功賃金制度に基づく年少労働であるが故の 低賃であることを観察すれば，労働の問題も，本工 業の立地上特に重要な意義を有するものではない。
4) 運送 Parts Maker の多くは，Chassis Makerに時間供給している．遠隔地の完成部品 Maker は毎日納入しているが，単一部品 Maker は親工場 ない. Chassis Maker は倉庫を持たないが，Parts Maker はトラックを持つて，両者は便利な道路で 結ばれていなければならない，距離の遠近が運賃の 高低に影響して収益性を左右するという問題は少な いが，近い時間距離のうちにあつて，早くと言うょ りも交通難や天贸に妨げられることなく，確実に納 入される体制にあることが望まれる。 の組立 line の進行に合わせて納入しなければなら

47）日産は，1956年から農工労務者登録制度を採用した。目額4, 000〜 5,000 円（手取）で，約 1,000 人を擁し た。

48）通産省重工業局自動車課（1955）：自動車部品工業の実態. 自動車時報，26，83～99.

49）中沢武雄（1959）：自動車部品工業. 機械工業の近代化と雇用構造，197～215.

50）向坂正男・三輪芳郎（1959）：自動車工業，前揭49）. 107～137.

51）前揭38)，p.224. 
5）市場 Chassis Maker は專門の販売業者を 各地に持つて，これを通じた販売政策を行なつてい るが52)，自動車工業と市場の関係は Body Maker を媒介として結ばれている53). Chassis Maker で生 産される車台は自己搬送されるが，Body Maker で 架装される車体は大型であり，かつ他の輸送機関に よらなければならない，トラックなどの車体は，需 要者に応じて各種各様に架装されるものであり，地 方的特色をもつて各地に散在されていることが望ま ᄂ( 54$)$.

しかし，バスなどの車体の架装は特殊技術を要す るものであつて，航空機産業から転換したものが， 主としてこれにあたつている。この種の企業は規模 も大きく，特定地域に集中して，Body Makerの中 核的存在である。すなわち，大都市大工業地帯の衛 星地域にあつて，全国の数地方に集団化する航空機 産業の分布を継承した。それは，広大な土地と国防 的要因に基ついて，工業核心地域から遠心的移動を 困り，関連産業の及ふ範囲内の平坦地に立地した航 空機産業の残象が，地理的に復活した結果である. それは，技術的・資本的に Body Maker 立地の基 体となり得たことのほかに，Chassis Maker から需 要者のいる市場へ近づいたことでもある，運賃は原 洒の $1 \%$ 以下でそれ和問題にならないが，車台を 搬送する運賃よりも完成車を搬送するほうが高くつ く. Body Maker によつて完成車になる地点が，市 場に近づけば，それだけで運賃費用は安くなる。

自動車工業の立地要因は，
1) Chassis Maker-土地 - Parts Maker

2) Body Maker一一市場

3) Parts Maker-Chassis Maker (単一) 関連産業（完成）

に要約されるが，自動車工業立地の基体となつた機 械工業が，独自の性格をもつ三業態に分化して，そ れが自動車を生産する一つの目的のために，どのよ うに結合・統一されているか. 本工業の地域的展開 の構造は，それらの地域的組合わせの結果として理 解される.

\section{IV 分化と結合}

関東工業圈では，あらゆる部品が生産されて， Chassis Maker に供給されている．しかし，中京の Parts Maker は不完全であり，阪神には Chassis Maker が存在しない.

1）部品の流動 京浜 2 社 ${ }^{15)}$ ・東京 3 社 ${ }^{56)}$ の他工 業圈への部品外注度は低いが，中京 1 社の部品は相 当量が京浜にも阪神にも依存されている，中京 1 社 が当該工業圈の中で $100 \%$ を確保している部品は電 装品類であつて，これは東京 3 社に対しても同必要 額の $23 \%$ 怘給している。しかし，車体・懸架・用 品類の $50 \%$ 内外は京浜に依存している. 阪神部品工 業の特色は伝導部品類の生産にあつて，京浜地域消 費量の約15\%を下請け生産している。そのほか，阪 神地域の部品工業は，中京地域の不足品類を補なつ ているが，補修用部品を生産することに最も特色が ある.

2）関西圏 輸大部品の関税が上がつて部品工業

52）Chassis Maker が別に独立して持つ販売業者は，トヨタの109店を最高にして，三菱ふそうでも31店を持 ち，各県 1 店以上，主要地方都市に配置している。中小規模のトラック Body Maker は，これと同一の 分布と性格を有する。

53）Chassis Maker が特定の市場地域を対象とすることなく，全国に普遍的である. 中京T社の製品出荷状 況をみても関東以東の $44 \%$ に刘して関西以西 $39 \%$ あるる.

54）米作地域では米俵に適合した寸法の荷台を，䁔造地域では酒樽に適合した寸法の荷台を設計して架装す るように一一。

55）日産およびいすぐ。

56）日野・民生・富士精密. 
第 9 表 部品 の 流動 (1955, 奶品目)

\begin{tabular}{|c|c|c|c|c|c|c|c|c|c|}
\hline \multirow{2}{*}{$\frac{\text { 親工場 }}{\text { 供給圈 }}$} & \multicolumn{3}{|c|}{ 中京 1 社 } & \multicolumn{3}{|c|}{ 京浜 2 社 } & \multicolumn{3}{|c|}{ 東京 3 社 } \\
\hline & & $\begin{array}{l}\text { 中 } \\
\text { 京 }\end{array}$ & $\begin{array}{l}\text { 京 } \\
\text { 浜 }\end{array}$ & $\begin{array}{l}\text { 阪 } \\
\text { 神 }\end{array}$ & $\begin{array}{l}\text { 中 } \\
\text { 京 }\end{array}$ & $\begin{array}{l}\text { 京 } \\
\text { 浜 }\end{array}$ & $\begin{array}{l}\text { 阪 } \\
\text { 神 }\end{array}$ & $\begin{array}{l}\text { 中 } \\
\text { 京 }\end{array}$ & $\begin{array}{l}\text { 京 } \\
\text { 浜 }\end{array}$ \\
\hline 関 & 16 & 48 & 36 & 4 & 20 & 76 & 3 & 5 & 92 \\
\hline 電 装 & 0 & 100 & 0 & 5 & . & 92 & 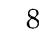 & 23 & 69 \\
\hline 伝 導 & 57 & 5 & 38 & 12 & 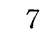 & 81 & 17 & . & 75 \\
\hline 懸 架 & 0 & 44 & 56 & 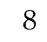 & 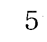 & 81 & 3 & 19 & 78 \\
\hline 用 品 & 40 & 12 & 48 & 0 & & 100 & 0 & & 100 \\
\hline 車 台 & 0 & 58 & 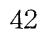 & 7 & - & & 0 & 0 & 100 \\
\hline 車 体 & 19 & 10 & 63 & 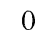 & & & 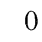 & 0 & 100 \\
\hline 工 具 & 50 & 25 & 25 & 0 & 0 & 100 & 33 & 17 & 50 \\
\hline
\end{tabular}

が成長した時には，既に現在の Chassis Maker の 立地が終つて，本工業の確立がほぼ決定的になつた 時である。それ以降は，軍需産業が主導的となり， 新たな本工業の立地発生をみることは不可能であつ た。戦後の激しい存続可否論の中では，阪神地域に 新たな本工業の発生を望むことは無理である。最近 になつて，三輪車 Maker であつたダイハッが小型 四輪トラックの生産に進出し，さらに軽四輪車から 完全四輪 Maker へと，生産重心の移行を図つてい るようである57， 補修用部品の生産は全品目にわた つて，充分な Parts Maker を擁する本工業圈は， Chassis Maker の発生が今後に期待される. 本工業 圈では，他の工業圈の Parts Maker がそれぞれの 地域の Chassis Maker の傘下に属しているょうに， 生産部品の主要納入先である輸出業者を始めとする, 主として商業資本の下に企業結合されている。

3）工業圈の構成 自動車工業の分布の中心は， 地理的にも経済的 ${ }^{58}$ にも，Chassis Maker である。 工業圈は，3 業態の分布する核心地域を中心にして， Body Maker と Parts Maker の 2 業態が分布する 衛星地域と対になつており，さらにその外側に，関 東工業圈におけるが如く，Parts Maker の単独地域
を配置させている，関酉工業圈においては，Chassis Maker にかわつて，輸出業者等の部品商業資本が そのイニシアティブをとり，中京には部品工業の単 独地域がまだ配置されていない。その結果，現在で は，3工業圈の間で部品の流動が行なわれている. しかし，基本的には，関東工業圈についてみられる ように，Chassis Maker を中心にした自動車工業核 心地域と, 車体工業衛星地域, 外辺部品工業地域の 3 地域から一つの工業圈が構成されるものと思われ る。そして，一つの工業圈は，一つの生産目的に必 要な全てを充足する体系をもつて，統一地域と理解 される。この地域構成の原理が，展開される工業立 地の地域的配置を決定する.

4）工業圈の競合 この工業圈が完成され，拡大 し，接触すると，両工業圈の競合が行なわれる。衛 星地域にある Body Maker は, 航空機産業から転 換してきたものであるが，その最初は，該工業圈の 核心地域にある Chassis Maker と系列を組んで， 車体の生産に従事することによつて始まつた。すな わち，核心地域の機能の一部を遠心的に派出させた 結果であり，圈全体の中央に位置することは，圈全 域にわたる市場と工業の核心地域に重合している市 場の核心地域の両者に対して，地理的好位置にあつ た.しかし，衛星地域が車体工業地域としてょく発 達し，多くの市場の核心地域を独占する必要が生じ てくると, Chassis Maker は他の工業圈の衛星地域 にある Body Maker と企業系列を結ぶようになつ た.すなわち，トヨタが横須賀の関東自工で車体架 装するのに始まり，最近では，いすぶが岐皁の川崎 航空と企業系列を結ぶことによつて，この地域の市 場圈を確保しようとしている。 5 車体工業地域はそ れをそれ独自の市場圈を持つている，Chassis Maker は，5車体工業地域に必らず一つ以上の系列 Body

57）自動車産業. 自研社，1960年 9 月号.

58）公正取引委員会（1959）：自動車工業の経㴮力集中の実態. 
Maker を持つことによつて，その後背としている 市場に侵透し，需要供給の増大を困ろうとしている。 それは，Body Maker の立地意義を正しく活用する ものであり，Body Maker が販売業者 Dailer とと もに Chassis Maker の重要な販売部門を分担する ゆえんである。

このことは，Chassis Maker の重要な生産部門を 分担する Parts Maker が，いまだ発達不十分で， その機能がやむなく 3 工業圈に分化されていること と著しく対照的である，販売を旨とする工業は，工 業圈の完成を待たずして，工業圏をこえた競合を， 衛星地域の Body Maker を介して行なつている. それは，日本の自動車工業が，堅固な基礎なくして 不安定に発展している経済的現状とも符合する。

\section{$\mathrm{V}$ 地域の構成}

京浜地域における自動車工場の分布は，臨海地域 の Chassis Maker を中心にして拡大している。そ の外側に Body Maker が分布し，Parts Makes は 内陸部にわたつて分散的である。海岸が自動車工場
部品工場 0

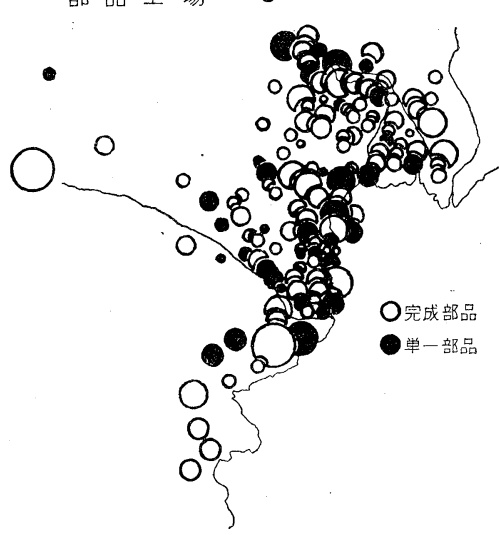

車体工場

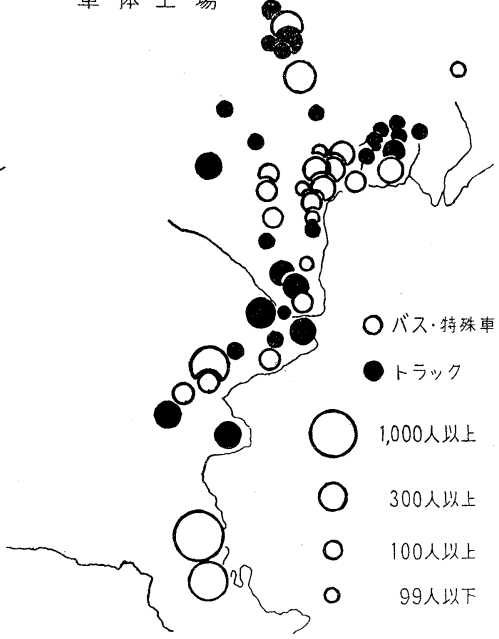

第3図京浜自動車工業地域
集積の中心になつていることは，海岸の立地意義が 評価されるのではなく，歴史的に Chassis Maker が臨海工業地域に立地した地理的習慣性の残象 59 で あり，今な括湩し続ける顕象である.おもなる Chassis Maker は，深川から横浜に至る $1 \mathrm{~km}$ 以内 の臨海地区を移動南下して，今日の分布をみる。そ こで，自動車工場数 $(\mathrm{Y})$ の隔海度 $(\mathrm{X})$ 分布を考 察してみた ${ }^{60)}$ (第 4 図参照).

その結果, Parts Makes は $\mathrm{Y}=-2.36 \mathrm{X}+41.22$ ， Body Maker は $\mathrm{Y}=-2.65 \mathrm{X}+23.45$, 同様の傾向 からして Chassis Maker はY $=-3.00 \mathrm{X}+8.00$ と 計算された，定数の確定には，な抢充分な考慮を要 するが，ほぼ同一の傾斜をなして，内陸部へ向かう にしたがつて工場の分布が減少して行つている. Chassis Maker へ近ずくにしたがつて，1 km あた り $2 \sim 3$ 工場ずつ，それぞれの分布が増加している. Parts Maker が Body Maker の分布しない内陸部 にわたつて分散的であることは，Parts Maker の絶 刘数が Body Maker より多い結果であつて，Chassis Maker に対する集中 傾向は，ほぼ同一である。 ただ，Body Maker よりも Parts Maker のほうが，よ り多く, Chassis Maker の 周辺に集積する必要がある。 しかしここに計算された 比例定数を信頼するならば， Parts Maker よりも Body Maker のほうが，Chassis Makerに対してやや強い集 中傾向を示す.

自動車工業が 1 工場分布 する隔海限度は，Chassis

59）田中啓爾（1949）：地理学の本質と原理。

60）小川一朗（1958）：工業集積の地位層. 地理的総合研究， $71 \sim 87$. 


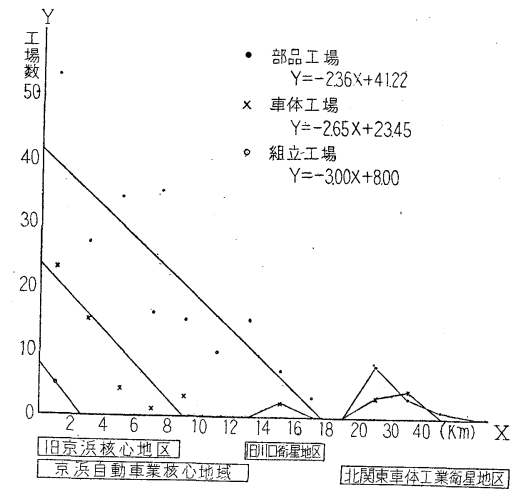

第 4 図 京浜地域自動車工場の分布と工業 圏の形成

Maker $2.35 \mathrm{~km}$, Body Maker $8.47 \mathrm{~km}$, Parts Maker $17.04 \mathrm{~km}$ で，この地点までは一連の分布傾向を 示す。さらに，Body Maker ではその外側 $16 \mathrm{~km}$ 附 近，Parts Maker では 30km 附近にやや高い集中 的分布が見られる。前者は川口の車体工業であり， 後者は東松山を中心とする部品工業であつて，その 分布形態は衛星地域的である。自動車工業全体の分 布からみれば，東松山周辺の部品工業は，桐生・伊 勢崎地区の車体工業とともに京浜核心地域の北関東

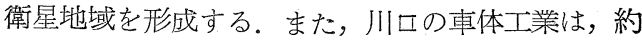
$17 \mathrm{~km}$ 以内の地点まで部品工業が一連の分布を示す 京浜核心地域の中に包括される。

発展的に観察するならば，8～9 km 以内の地点 まで車体工業が分布している京浜地区と，歴史的に その衛星地域であつた川口地区が，一連の傾向によ つて連携されることにより，京浜核心地域が形成さ れた。ささに発展することによつて北関東衛星地域 が派生され，これもやがては一連の大京浜工業地域 のうちに包含される初象と解される，また，この分 布からも，自動車工業の地域的展開の核心となるも のは 3 業態の重合分布している地域であつて，その 外側に Body Maker・Parts Maker 2 業態の, 一 番外郭に Parts Maker の単独分布地域が配置され ている.この地域的展開の形態は，前述の衛星地域

派生の構造とともに関東自動車工業圈全体について も布廷される。

中部や関西自動車工業圈は，その形成が不完全で あつたり発達の事情を異にして，やや不明確ではあ るが，同様の地域的展開の構造を観察することがで きる．中部工業圈の核心は，挙母・名古屋・刈谷の 三角地区であるが，その中心はもとょり挙母であつ て，その外側に Body Maker の卓越している名古 屋・刚谷地区，さらにその外側に Parts Maker だ けの西枇杷島および碧南地区がある。このようにし て形成される核心地域の外郭には，岐皁・犬山の車 体工業を中心とした衛星地域が形成されている，阪 神地域には Chassis Maker はないが，分布の中核 となるものは布施・東成地区の部品輸出業者と結び ついた Parts Maker であつて，これを中心に本工 業の分布が展開されている。

京浜地域の Parts Maker の分布について（第5 困参照)，親工場を中心とした地域的展開の状態を 考察すると，機関・伝導・用品類では顕著な傾向を 把握することができた。そのほかの部品類について は一定の傾向が認め得られないのは，それらの工業 が独自の立地形態をとるためである。鋳造や機械加 工による単一部品の多い機関用部品類の生産は， Chassrs Maker の近傍にあつて最も集中的である。 続いて，伝導・用品類の順に配列され，それぞれの 中位値は親工場から $3.9 \mathrm{~km}, 7.6 \mathrm{~km}, 11.7 \mathrm{~km}$ ，偏 差值は $6.96 ， 8.97 ， 12.28$ となつてる。なお，機

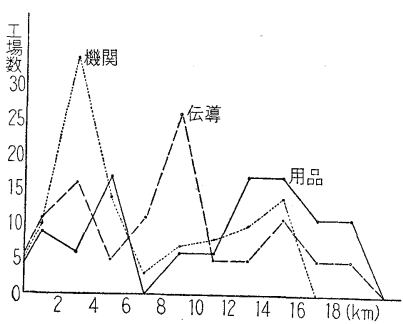

第 5 図 部品工場の親 工場からの配置
関用部品が遠隔地 に拈てて多い分 布を示しているの は，完成部品類を 含む故であり，用 品類の分布が近傍 地に打いても多い のは，兼業度の高 
い関連産業の分布が，歴史的に Chassis Maker の 分布と重合した結果である.かくして，この地域的 展開の構造もまた工業慻内部の Parts Maker 分在 の傾向について布廷される，すなわち，北信地域の 部品工業は，用品類を生産するものが多くて機関用 部品を生産するものは少ない。

自動車工業生産の地域的展開は，地域的立地因子 によつて決定されるのではなく，核心自動車工業地 域を中心に，衛星車体工業地域，外辺部品工業地域 と展開される工業圈の地域的配置の構造の中で決定 される. 工業生産が増大すれば，この地域的配置の 形態をそのままに，新しい展開構造へと拡大される.

\section{結語}

1）自動車工業の立地基体は機械工業であつた。

2）自動車工業の地域的展開は，組立工場を中心 にして配置されている.

3）組立工場は，優秀豊富な関連産業と広大安価 な土地を立地の要件とする．その結果，大都市の周 辺部に隣接して立地した。

4）車体工場は，需要の増大とともに市場に吸収 されてその分布を搪廷した。しかも，主導的な中核 となつて地域を形成したものは，航空機産業から転 換したものである．車体工業地域は航空機産業の分 布を継承して，核心工業地域の衛星工業地域として 復活した。

5）部品工場は，既に輸入されている外車用補修 部品を生産するために成長した。 その中で，核心地
域にあるものは，組立工場の柔列下に単一部品類を 生産する。また，完成部品類を生産するものは，後 背となつた関連産業としての独自の立地形態をとつ て，遠隔地に立地しても良い，地方の労働や工業化 と結びついた一部の蹯開産業は，自動車工業の発達 とともに外辺部品工業地域を形成した。

6）自動車工業の生産は，3業態の分布する核心 工業地域を中心に，車体工業衛星地域，部品工業外 辺地域によつて棈成される自動車工業圈の中で，統 一的に行なわれる.

7）この工業生産地域展開の拡大は，まず，核心 地域から車体工業に特色のある衛星工業地域を派 生することによつて始まる，やがて工業生産が増大 すると，衛星地域が核心工業地域の一連の延長の中 に包含される，そして，ふたたび新たな衛星工業地 域が形成される.

工業の立地は，既にある工業の立地の構造の中に 展開されるが，その地域的展開は常に一定の構造を 構成する.な掞，本論は分布と立地の統一的理解に 重点を抢き，資本や企業の微細な分析が軽視された。 これらのことが，日本の工業経済全体の中でどのよ うに位置づけられるかは，今後さらに研究したい。

本研究にあたり御指導頂いた田中啓爾，岩田孝三，姑田一二, 辻本芳郎, 山口貞雄の諸先生, 貴重な資料を提供して下さつた業 界関係団体，各社各位に対し心加威謝します。（1961年 3 月 16 日受理）

61） E. Otremba (1952) : Allgemeine Agrar-und Industrie geographie. 藪内芳彦（1957）訳：一般工業地 理学.

追記：トヨタ自動車の所在地挙母は，1960年，豊田と改称し，富士精密は1961 年プリンス自動車と改名し た。

なお，第 4 図最下段，京浜自動車業地域は京浜自動車工業地域の，北関東車体工業衛星地区は北関東車体工 業衛星地域の䛈まりである. 


\section{THE GEOGRAPHIC STRUCTURE AND DEVELOPMENT OF THE FOUR-WHEELED MOTOR VEHICLE INDUSTRY IN JAPAN}

\section{Yoshiyuki KITAMURA}

The Japanese motor vehicle industry produced 181, 893 four-wheeled vehicles in 1957. The motor vehicle industry has developed rapidly in the years following the World War II and has grown into a leading industry in Japan. The industry was originally started in Azabu district in Tokyo, due to the presence of wheel-smiths and electrical engineers just like in America. But this works transformed from the wheel-smiths disappeared, and the motor vehicle-works have developed from the machine industry.

The motor vehicle industry can be devided into three separate patterns; chassis makers, body makers and parts makers. The chassis makers, fewer in number, are the largest in scale and predominant over the industry. Their location is determined by the availability of large areas of inexpensive land and nearness to the related industries such as steel, machine and electricity. The body makers are greater in number but less in scale. They have grown from the post war aircraft industry and is located near the market. The parts makers are the most numerous but the least in scale, and are devided into two separate types. The small works producing single parts gather about the chassis maker. The location of larger works producing complete parts or accesories is influenced by their related industries. The distribution of the motor vehicle industry is separated into ten areas each producing chassis or bodies or parts or conbination of these.The conbination produced in each area determines the location and geographic expansion of the motor vehicle industry.

The machine industry had grown in the three central cities of Tokyo, Osaka and Nagoya, and promoted the growth of the motor vehicle industry. The chassis makers are located near the margin of the cities due to the locating factors of getting large and inexpensive land, and of nearness to the related industries. The body makers grew in various districts because of the increased demand since the Kanto Earthquake Disaster. But they have remained as the truck-bodies maker, to supply local demand in each metropolitan areas. The parts maker have grown, as the customs duty on imported parts had been increased. Its growth was at first in Tokyo and Osaka and aimed to supply the spare parts for imported motor vehicles. The development of the motor vehicle industry was much determined by military policy, and the import of motor vehicles were reduced while the need increased because of national defence. The location was affected as industries moved from the former places to the center of the industrial zones. The sircraft industry which became the body makers producing buss-bodies in the main was located as satellite areas at northern Kanto, Mino, and Kyoto-Uji.

The basic principle of growth has developed three uniform areas or zones of the motor vehicle industry in Japan at Kei-hin (Tokyo-Yokohama), Chukyo (Nagoya) and Han-sin (Osaka-Kobe). A chassis maker is situated at the center of a with body makers and parts makers gathered around. A zone has a core industrial area and has to dispose the satellite industrial area outside where the body makers have gathered. Some parts makers are related to other industries and are located further away at Northern Nagano These parts makers are producing the complete parts and accessories, and are consisting an area in the outside of the core and satellite areas. The core industrial area includes the chassis maker 
and parts makers producing the single parts with body makers outside, and other parts makers even further outside. This basic relation of the zonal arrangemeut is the same with every core areas. The localization of a chassis maker has grown the core industrial area and expanded the same regional structure around. And, the core industrial area expands larger to the zone by the growth of the industry.

But the motor vehcle industrial zones have not yet been completely developed in Han-sin and Chukyo because there are no farthest parts maker arease and in Han-sin as there is no chassis maker. This area originally produces spare parts but with the decrease in three-wheeled vehicles and the increase in fourwheeled vehicles the chassis makers will be developed. In addition to these areas there are two body maker areas at Hoku-riku and Northern-kyusyu as simillar charactor as satellite areas. And there is one tuberous industrial area at Tokai between Chukyo and Kei-hin core areas. The Japanese motor vehicle industry is developing even now. 